\title{
The Impact of Adoption of XBRL on Information Risk in Representative Countries of Scandinavian Region
}

\author{
Valentina Tohang, Michellen Lan
}

Department of Management Faculty of Business Binus University International Jl. K.H. Syahdan No.9 Kemanggisan, Palmerah, Jakarta, 11480, Indonesia

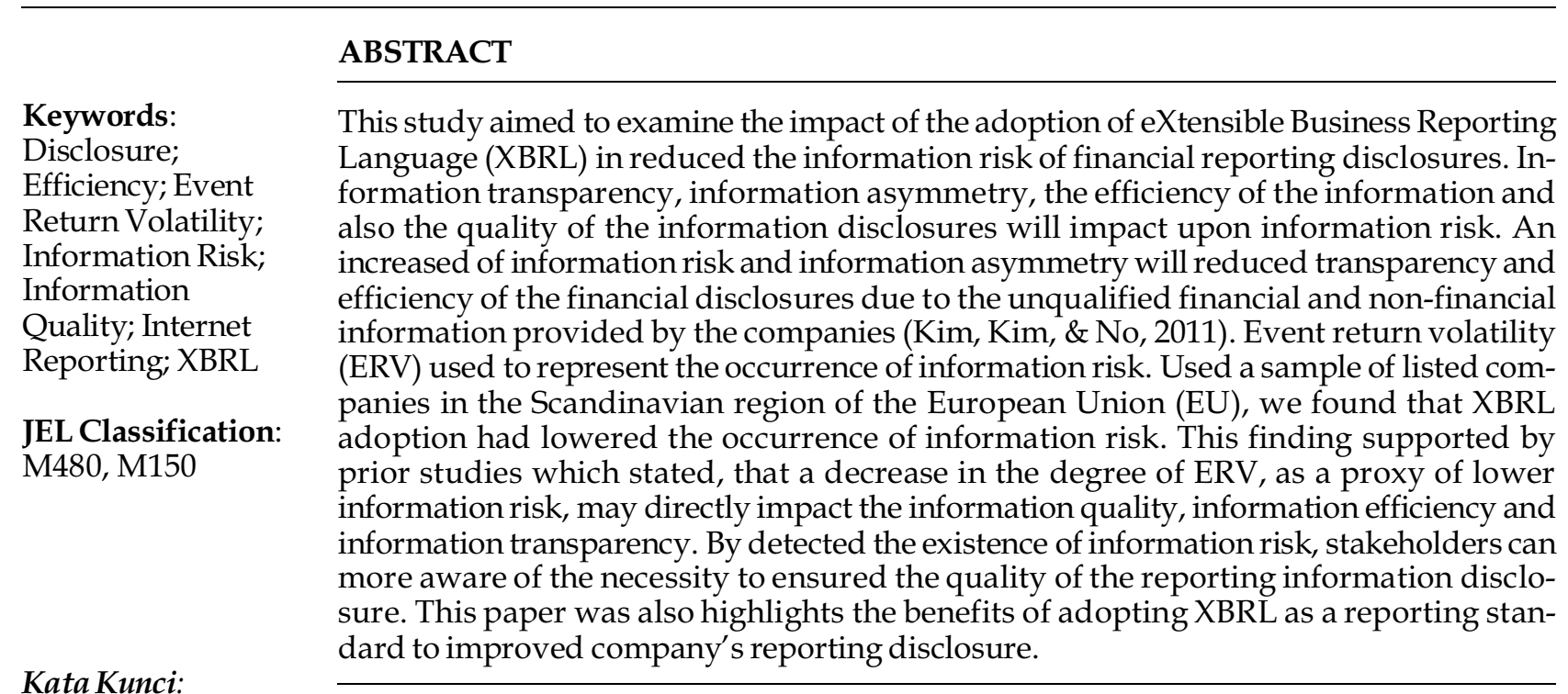

Pengungkapan;

Efisiensi; Event

Return Volatility;

Risiko Informasi;

Kualitas Informasi;

Pelaporan Internet;

ABSTRAK

Penelitian ini bertujuan untuk menguji dampak pengadopsian dari Extensible Business Reporting Language (XBRL) dalam mengurangi risiko informasi dari pengungkapan pelaporan keuangan. Transparansi informasi, asimetri informasi, efisiensi informasi dan juga kualitas pengungkapan informasi akan berdampak pada risiko informasi. Peningkatan risiko informasi dan asimetri informasi akan mengurangi transparansi dan efisiensi pengungkapan keuangan karena informasi keuangan dan non-keuangan yang tidak memenuhi syarat atau tidak sesuai standar perusahaan (Kim, Kim, E No, 2011). Event Return Volatility (ERV) digunakan sebagai variabel yang merepresentasikan risiko informasi. Dengan menggunakan contoh perusahaan-perusahaan yang terdaftar di wilayah Skandinavia, Uni Eropa (UE), peneliti menemukan bahwa dengan mengadopsi XBRL telah menurunkan terjadinya risiko informasi. Temuan ini didukung oleh penelitian sebelumnya yang menyatakan bahwa penurunan tingkat $E R V$, sebagai proxy dari risiko informasi yang lebih rendah, dapat berdampak langsung pada kualitas informasi, efisiensi informasi dan transparansi informasi. Dengan mendeteksi adanya risiko informasi, pemangku kepentingan dapat lebih mengetahui perlunya memastikan kualitas dari informasi pelaporan. Artikel ini juga menyoroti manfaat penerapan XBRL sebagai standar pelaporan untuk meningkatkan kualitas penyajian laporan perusahaan. 


\section{Jurnal Keuangan dan Perbankan | KEUANGAN}

Vol. 21, No. 4, Oktober 2017: 515-526

In a business, information is valuable for all the stakeholders in taking various actions and decisions. Due to the technology advancement in business world, information technology (IT) based corporate reporting information is considered more effective and efficient to be used for decision making rather than traditional paper based reporting, as it has becoming less timely and thus less useful for decision making process (Debreceny, Gray, \& Rahman, 2003). On the other hand, IT based information also has risk factor of various negative and positive outcomes (Gaftea, 2014). It may bring potential harmful effects for the use of technology and information in reaching the objectives (UK National Archives, 2011). Major risks can be mitigated by implementing standards, policies, procedures, and risk protection planning to overcome these risks. Nowadays, every element and evaluation of risks relating to IT such as information risk had become the main priority. There are 2 perspectives of information risk. The first perspective is about the IT security risk that potentially brings harmful effects towards the process or related information due to some deliberate or accidental event that might negatively impact to the process or the information itself (Elky, 2006), whereas the second one is more focused on the potential effects towards information disclosures quality to the shareholders in making qualified decision.

This second perspective emphasizes on how the information risk has become one of the main priorities in the evaluation of risks related to information technology, it is the potential effect of information disclosure quality on the shareholders in making qualified decisions. It also refers to the possibility for companies' specific information to be presented in low quality (Francis, Nanda, \& Wang, 2006). The occurrence of negative impacts towards the companies' information disclosures might happen if the organization is lacking in information management. They may lack the proper allocation of documents or the ability to manage and gain accurate information. Information transparency, information asymmetry, efficiency of the information, and also the quality of the information disclosures will impact upon information risks (Kim, Kim, \& No, 2011). Having such awareness of information risks will change stakeholders' perspectives in using particular information as they will reevaluate and asses the information a number of time before completely relying on particular information.

Based on prior studies developed in the United States, the occurrence of information risks were detected using various methods. Information risks are measured using several proxies: (1) earnings surprise, (2) event return volatility, (3) information efficiency, (4) the change of standard deviation of daily returns, and (5) the change of standard deviation of analysts' earnings forecasts (Kim, Kim, \& No, 2011; Sen, 2009). Event return volatility (ERV) is chosen for this study to indicate unexpected return, which is an abnormal (excess) return of stocks compared with the market's reaction, since a decrease in ERV will directly lower the occurrence of information risk in a particular market environment (Bushee \& Noe, 2000). ERV is determined by the prices that investors discover from the stock market due to the uncertainty of the future profitability of companies. This measurement helps investors predict the risk and future economic performance.

According to Anagnostopoulou \& Tsekrekos (2015), an increase of ERV will bring an increase in the occurrence of information risk that may cause a low quality of reporting information provided by the particular companies. While a decrease in ERV prevents the likelihood of the occurrence of information risk and may also giving a higher degree of quality to the financial and nonfinancial information being reported.

In order to reduce the information risk, the adoption of the new reporting information technologies is applied through the use of eXtensible 


\section{The Impact of Adoption of XBRL on Information Risk in Representative Countries of Scandinavian Region}

Valentina Tohang, Michellen Lan

Business Reporting Language (XBRL). There are 2 major problems that are mainly solved by the XBRL: (1) the efficient preparation of financial information and (2) extraction of the specific detailed information of the different forms of financial statement around the world (Bhasin, n.d.). XBRL can help the information disclosures in increasing the accuracy, speed and usage of the data itself (Bonsòn, 2001). XBRL provides several ways to reduce informational risks, such as converting one document into other forms such as Microsoft Excel, HTML, and PDF, without having to lose the accuracy and integrity of financial information (Lester, 2007). It is a part of XML-based technology for the purpose of creating, preparing, exchanging, and distributing financial information (Kim, Kim, \& No, 2011). The use of XBRL would help companies to distribute and display data across the country, without the necessity to retype data (Blankespoor, Miller, \& White, 2014). Through the use of standardized data, it may lead to greater transparency, lower cost and also higher quality in decision-making (Willis, Tesniere, \& Jones, 2003)

Currently, researchers that are focusing on information risk have different understanding towards the risks, as they are more focused on the technical areas rather than the quality of the information itself. However, this study focuses in the areas of information disclosures, where risk appears from the gap between actual information provided by the companies and the analysts' expectations. An increase of information risk and information asymmetry will directly affect the transparency and the efficiency of the financial disclosures to be lower due to the unqualified financial and non-financial information provided by the companies (Kim, Kim, \& No 2011).

This research scope is focusing on Denmark, Sweden, and Finland by investigating the impact of adopting XBRL on the occurrence of information risk. The European Union (EU), of which they are members, implements XBRL with a focus on government-wide purposes. As noted by the IFRS foundation, the EU is not a union with a single regulatory authority, instead it is an economic and political partnership with 28 countries as its members. The objective of this study is to investigate whether XBRL will reduce the information risks of financial reporting disclosures.

\section{HYPOTHESES DEVELOPMENT}

\section{Information Risk}

Information risk obviously can be seen from many different perspectives. Some previous studies focused on the information risks as an IT security paradigm, some on a technical area and more focus on information asymmetry rather than information risk. However, in this paper, the authors would like to further discuss the impacts of information risks, which are the quality and efficiency of the information as well as the transparency of the information, since the occurrence of information risk is due to unqualified companies reporting information in relation to the poor decisions made by investors (Francis et al., 2005; Jiang, Lee, \& Zhang, 2005). An increase in information risk will reduce the information quality and information efficiency, which may also directly impact upon the transparency of the information especially for the stakeholders that might face difficulties in making decisions to meet the company's objectives (Kim, Kim, \& No, 2011; Hannon, 2005).

In order to detect the occurrence of information risks, Event Return Volatility (ERV) is used as the measurement of the occurrence of information risk (Kim, Kim, \& No, 2011; Anagnostopoulou \& Tsekrekos, 2015), including the independent and control variables that have been selected as the factors affecting the occurrence of information risk. Previous studies have stated that the occurrence of ERV can help to mitigate the fluctuations of earnings surprises towards information efficiency (Kim, Kim, \& No, 2011). Furthermore, an ERV will have positive impacts towards quality of 


\section{Jurnal Keuangan dan Perbankan | KEUANGAN}

Vol. 21, No. 4, Oktober 2017: 515-526

information disclosures, which motivates the managers to reduce possible occurrence of information risk by implementing qualified levels of disclosures (Bushee \& Noe, 2000). ERV is a proxy used to measure the occurrence of information risk in the market environment. ERV is determined from the prices at which the investors transact in the markets. It also has a close relationship with the earning quality as it might appear due to the uncertainty of future profitability. It helps investors to forecast about risk and future economic developments. It is believed that poor quality of accounting information will be able to be detected from the high degree of ERV which shows a high degree of information risk occurrence (Anagnostopoulou \& Tsekrekos, 2015).

\section{The Transformation of XBRL towards the Reporting Disclosures}

The use of internet financial reporting has been considered as one of the solution to mitigate the problem of information inefficiency (Verrecchia, 1983). Nowadays, an increase in technological prowess has made significant improvement towards technological financial and non financial reporting through the use of system software (Venter, 2002). Traditional reporting can dissolve as soon as time passes by and new reporting systems have been created (Beattie \& Pratt, 2003). Internet financial reporting has increased the intention of several parties in managing the reduction of cost, reducing time taken in preparing financial reports as well as reducing the needs of supplementary information for the investors (Bonson \& Escobar, 2006). Further stated by Venter (2002), the main benefit of adopting internet financial reporting is to improve traditional financial reporting and encourage companies to gain access to potential investors. Lack of a structured data format in reporting financial disclosures will lead to users facing difficulty in understanding and analyzing information.
Starting from the mid 1990s, majority of companies are relying heavily on the use of World Wide Web (known as the Web) for disclosing their corporate information (Debreceny \& Gray, 2001). This way of disclosing is normally done in own corporate websites and are often uploaded in the form of Portable Document Format (.pdf) or Hyper Text Markup Language (.html), which enables the documents to be viewed and transferred electronically. However, stated that the information included in the web based disclosures is not made to be analyzed automatically and the content of these documents cannot be transferred into spreadsheets or other analytical software applications, which makes data search and financial analysis becomes uneasy, time consuming, and prone to potential errors (Debreceny \& Gray, 2001). These factors will limit the ability of the stakeholders to conduct various type of financial analysis and ultimately it will decrease their decision making capabilities. Thus, improvements in web based disclosures are needed to meet its stakeholders' demand, one of the method is by the implementation of XBRL (eXtensible Business Reporting Language) (Yoon, Zo, \& Ciganek, 2011).

Apparently, XBRL works differently compared to the commonly used web based disclosure format (i.e. HTML and PDF), XBRL does not treat financial information just as a simple block of text in a web page or printable document (Rayner \& Chandler, 2008). The format of XBRL works through the process of unique identifying tags for each financial data inside the documents which enables the data to be specifically identified, sorted, and automatically extracted by various analytical software (Li et al., 2006; Yoon, Zo, \& Ciganek, 2011). Each unique tag is developed and standardized based on the accounting standard of related country and stored in the taxonomies (data dictionaries) (Chen, 2012). Hannon (2005) explained that 90 percent of the tagged data elements to be used for financial reporting are provided from the XBRL standard industry tax- 


\section{The Impact of Adoption of XBRL on Information Risk in Representative Countries of Scandinavian Region}

Valentina Tohang, Michellen Lan

onomies, which is developed by each country's regulators based on the international XBRL guidelines. The remaining 10 percent will be companyspecific tags which can be modified to meet different needs of different companies (Hannon, 2005; Eierle, Ojala, \& Penttinen, 2014). These standard taxonomies will ensure the uniformity of the tags used by each company, and increase the degree of comparability of the final disclosed documents among companies. Additionally, the use of tags places the information in a computer-readable format with powerful search capabilities to assist users of financial reports in obtaining accurate and efficient information (Kernan, 2008; Yoon, Zo, \& Ciganek, 2011; Wang, Wen, \& Seng, 2014). XBRL tagging process also creates the relationships among items in the reports, identify the particular groupings of the items ( $\mathrm{Li}$ et al., 2006), and assist the integration of the whole items in the financial reports (Wang, Wen, \& Seng, 2014). Hence, XBRL taxonomy enables an automatic data retrieval as well as automatic control during the preparation of the reports by ensuring that all of the required data elements processed into the system are accurate (i.e. free from error in calculation) and aligned with the reporting rules and standards.

XBRL is an open standard format for data structures that users can use in preparing and publishing financial report disclosure over and across countries (Kim, Kim, \& No, 2011). It is a new method for disclosing both financial and non-financial information in the web, and it allows the information to be transferred into spreadsheets and processed through analytical software. It is also a framework that helps in simplifying the exchange of financial and non-financial information such as financial statements, performance reports, accounting records, management notes, auditors' report, and other business information through the use of software (Hannon, 2005). It is a part of XML (Extensive Markup Language) that enables information to be exchanged, extracted, analyzed, and further processed in an effective way (Hannon,
2005). XML is a base language that was invented by Charles Hoffman in 1988. He investigated the usage of XML in terms of financial reporting information, which would later be known as XBRL (Bonsón, Cortijo, \& Escobar, 2009). Through the use of XBRL, financial reporting standards such as IFRS can be applied into the software system and all financial and non-financial information can be enclosed by the XBRL tagging process, in which it will give semantic information that makes reports not only readable to the human language but also be readable by computer language (Wu \& Vasarhelyi, 2004). The implementation of IFRS along with the use of XBRL as a mandatory financial reporting standard, has made a significant improvement to the global business reporting process (Bonsón, Cortijo, \& Escobar, 2009).

In this study, the implementation of XBRL through the use of digital financial reporting by creating a simple and structural financial report (Debreceny \& Gray, 2001; Ponte, Gallego, \& Rodríguez, 2009), is a potential tool to better improve financial statements disclosure. XBRL is a standard method for structuring the data format to prepare, publish and exchange information from one party to another (Kim, Kim, \& No, 2011). The use of XBRL will result in a reduction of time and cost. Financial and non-financial information can also be recorded in simple, structured formats, and enable users to learn and understand easily (Stocken \& Verrecchia, 2004). There are 2 major problems which are solved by the adoption of XBRL: (1) the efficient preparation of financial information and (2) extraction of specific detailed information with different forms of financial statement around the world (Bhasin, n.d.). XBRL can help the information disclosures in increasing the accuracy, speed and usage of the data itself. Through the use of standardized data, it may lead to a greater transparency, low cost and also higher quality in decision making (Willis, Tesniere, \& Jones, 2003). 


\section{Jurnal Keuangan dan Perbankan | KEUANGAN}

Vol. 21, No. 4, Oktober 2017: 515-526

\section{XBRL Adoption in European Union (EU)}

The implementation of XBRL has been adopted by many countries. With the proven benefits, countries all over the world are starting to adopt the XBRL for disclosures related activities which are designated to all public companies that operate in its jurisdiction. Based on a survey conducted by XBRL International (XBRL International, 2013), the number of public XBRL disclosures around the world is showing an upward trend from 2008-2014 and predicted to increase further in the future. This global adoption of XBRL has also expanded with organizations committed to extend the use of standards taxonomy (Bonsón, Cortijo, \& Escobar, 2009). The countries that decided to adopt XBRL have their different purposes of adoption. Some adopts XBRL for the reporting disclosures in capital market while some has more focus in government wide purposes such as tax regulators and financial regulator purposes.

Figure 1 is a diagram to illustrate the stakeholders and developed taxonomies of XBRL.

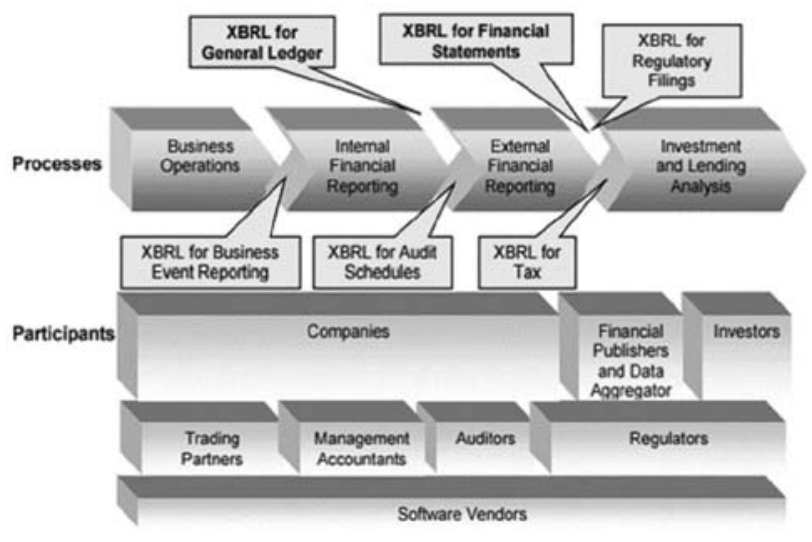

Figure 1. The Stakeholders in Adopting XBRL (Müller-Wickop, Schultz, \& Nüttgens, 2013)

However, the implementation of XBRL around the world is proven to be uneven due to different purposes of adoption and the different level of regulations imposed in each country
("XBRL, 2013," n.d.). In this study, the authors would like to investigate XBRL adoption in the European Union (EU), since it has brought major changes in this area. With the main focus of government wide purpose, the 28 countries of the EU have developed one set of global regulations and standards (Ponte, Gallego, \& Rodríguez, 2009). Every country of the EU is expected to have the same adoption of IFRS as the main accounting standard. The mandatory regulation of XBRL has made public-listed companies in the EU adopt IFRS (International Financial Reporting Standards) in reporting the company's financial information, in order to support the IASB (International Accounting Standard Board). The IASB has encouraged companies in EU to accept the adoption of XBRL in preparing the company's financial information as advised by the EFRAG (European Financial Reporting Advisory Group) (Inchausti, 1997). By adopting XBRL and IFRS as the European mandatory regulations and standards, it is easier for respected parties to review and analyze the information without having to lose the integrity of the information (CESR, 2010). XBRL has also made the spreading of information from one company into another more effective and timely (Lymer, 1999). With more transparency, the data should be more reliable for the users to rely on the reporting information (Kim, Kim, \& No, 2011).

Meanwhile, by using XBRL as an effective distribution of cross-country financial information will help the European commissioner to provide an appropriate advice on policy issues related to the securities. In EU there are many representatives involved in decision making, such as states members, representatives of the commission, observers from the European Central Bank, committee of the European securities regulators and candidates of various countries (European Commission, n.d.). Additionally, an independent EU authority known as ESMA (European Security Market Authority) has the responsibility to protect 


\section{The Impact of Adoption of XBRL on Information Risk in Representative Countries of Scandinavian Region}

Valentina Tohang, Michellen Lan

stabilization of the EU's financial system through the process of assuring transparency, integrity and function of the information provided towards investors' protection. XBRL will help ESMA as an independent security market authorization to supervise the other securities and financial regulators. Implementing XBRL will help ESMA to gain better benefits towards reporting disclosures which expected to reduce the occurrence of information risks (ESMA, n.d.). Through this framework, this paper is constructed using the following hypothesis:

Ha: companies adopting XBRL will have a lower degree of information risk

\section{METHODS}

This paper applies a longitudinal study with a four year time frame, 2 years before the adoption of XBRL, and 2 years afterwards. The data is taken from European publicly listed companies of OMX NASDAQ, which composed of Scandinavian Stock Exchange as a set of sample. The annual report, quarter report, and relevant stock prices data are taken from the prior and post year, in time when the particular countries adopted XBRL, in order for authors to measure the fluctuations of informational risk frequency. OMX NASDAQ has one of the major European stock exchange market, focusing on the Scandinavian areas within EU, and consists of 4 countries of Denmark, Sweden, Finland, and Iceland. Within this stock market, the authors has specifically taken the main market, which is a regulated market that has concern in large companies within the EU and monitored by the national Financial Service Authority (FSA).

There are 360 company-year observations from 90 companies of each of the countries selected (Denmark, Finland, and Sweden) as shown in Table 1.
Table 1. Samples Description

\begin{tabular}{llr}
\hline Country in Scandinavian Area & $\begin{array}{r}\text { Number of } \\
\text { Companies }\end{array}$ \\
\hline $1 \quad$ Denmark (2012) & 30 \\
2 & Sweden (2005) & 30 \\
3 & Finland (2012) & 30 \\
Total Sample & 90 \\
& & companies \\
\hline
\end{tabular}

It is believed that ERV has a close and positive relationship towards the existence of information risk since it shows the relationship with the quality of the financial and non-financial reporting information provided by the companies (Bushee \& Noe, 2000; Verdi, 2006; Brown, Hillegeist, \& Lo, 2009; Kothari, Li, \& Short, 2009; Anagnostopoulou \& Tsekrekos, 2015). The authors used the model that had been developed by Kim, Kim, \& No (2011) and Anagnostopoulou \& Tsekrekos (2015), which will be used for the multiple regression analysis of this paper. The research model is expressed as:

$E R V_{i, t}=\alpha_{0}+\alpha_{1} X_{B R L e n v_{i, t}}+\alpha 2 S I Z E_{i, t}+\propto 3 L E V_{i, t}+\varepsilon_{i, t}$

Where:

ERV $_{\mathrm{i}, \mathrm{t}} \quad$ : event return volatility of company $i$ at time $t$

$\mathrm{XBRLenv}_{\mathrm{i}, \mathrm{t}}$ : dummy variable of XBRL reporting environment in European Union that takes value of 0 for prior and 1 for post implementation

$\mathrm{SIZE}_{\mathrm{i}, \mathrm{t}} \quad$ : company's size which is measured by normal logarithm of total equity of company $i$ at year $t$

LEV : company's leverage, measured by the total debts divided by total equity, of company $i$ at year $t$.

The dependent variable of ERV is considered to have positive impacts towards the mea- 
surement of information risk. A low result of ERV shows reduction of information risk, while a high ERV increases the occurrence of information risk. The formulae to calculate ERV is mathematically expressed as:

$E R V_{i, t}=\left(S T D\left(\left(C L S D\right.\right.\right.$ Stock PRC $C_{i, t}-C L S D$ Market PRC $\left.\left.C_{i, t}\right)-1\right) * S Q R T(262)$

\section{Where:}

$\begin{array}{ll}\text { ERV }_{\mathrm{i}, \mathrm{t}} & \begin{array}{l}\text { : event return volatility of } \\ \text { company } i \text { at time } t\end{array} \\ \text { CLSD Stock PRC }_{\mathrm{i}^{\prime} \mathrm{t}} & \begin{array}{l}: \text { closed stock prices of } \\ \text { company } i \text { at time } t\end{array} \\ \text { CLSD Market PRC } \mathrm{P}_{\mathrm{i}, \mathrm{t}-1}: \begin{array}{l}\text { closed market prices of } \\ \text { company } i \text { at month } t-1\end{array} \\ \mathrm{STD} & \begin{array}{l}\text { : annual standard deviation } \\ \text { of the difference between } \\ \text { the closed stock prices and } \\ \text { closed market price }\end{array} \\ & \begin{array}{l}: \text { square root of one year } \\ \text { trading days }\end{array}\end{array}$

The independent variable of this study is the XBRL reporting environment (XBRLenv), coded 0 to represent prior years and 1 to represent post years to analyze the impact of prior and after the implementation of the XBRL technology. The control variables of this study are size and leverage. Size is used to measure the book value of equity to assist in aggressive competitions. Leverage has close relations with the information risk as the high degree of likelihood that financial risk will occur. The companies will try to disclose more information to reassure users' confidence level in the market.

\section{RESULTS}

This section presents the research findings and will be followed by required discussion. The first analysis conducted is the descriptive statistics as presented in Table 2.

The minimum and maximum values of ERV are 0.386 and 1.087 respectively. The positive value indicates the occurrence of ERV in the final samples selected. The standard deviation of 0.167 indicates significant price variability.

The relationship of XBRLenv with ERV (0.552) has a negative correlation and the $\mathrm{p}$ - value

Table 2. Descriptive Statistics

\begin{tabular}{|c|c|c|c|c|}
\hline & ERV & XBRLenv & Size & Leverage \\
\hline Mean & & & 9.032 & 2.974 \\
\hline Median & 0.688 & & 8.954 & 1.51 \\
\hline Std. Deviation & 0.167 & & 0.58 & 5.388 \\
\hline Minimum & 0.386 & 0 & 7.587 & 0.001 \\
\hline Maximum & 1.087 & 1 & 10.642 & 37.573 \\
\hline Frequency value of 0 (prior) & & 180 & & \\
\hline Frequency value of 0 (post) & & 180 & & \\
\hline
\end{tabular}

Table 3. Correlation Matrix

\begin{tabular}{lrrrr}
\hline & ERV & XBRLenv & Size & Leverage \\
\hline ERV & 1 & & & \\
XBRLenv & $-0.552^{* *}$ & 1 & 1 & \\
Size & -0.044 & 0.059 & 0.054 & 1 \\
Leverage & 0.03 & -0.04 & \\
\hline
\end{tabular}

** Correlation is significant at the 0.01 level (2-tailed) 


\section{The Impact of Adoption of XBRL on Information Risk in Representative Countries of Scandinavian Region}

Valentina Tohang, Michellen Lan

shows a significant correlation of 0.000 . This result defines that XBRL has a negative and significant correlation, suggesting that ERV is significantly reduced after the adoption of XBRL, which may be caused by several factors including other industry effects that are not discussed in this paper.

The results of the main analysis are reported in Table 4 . The result shows the adjusted $\mathrm{R}^{2}$ of 29.9 percent which explains the percentage of variance in the information risk as measured by ERV. This model is considered statistically valid.

The regression coefficient of XBRLenv shows the value of -0.184 with a $p$-value of 0.000 . This result indicates that XBRLenv is deemed significant towards the dependent variable of ERV in the sample of the three countries. It shows a negative correlation with information risk.

\section{DISCUSSION}

This result defines that XBRL has a negative and significant correlation, suggesting that ERV is significantly reduced after the adoption of XBRL. Meanwhile, the control variables, size shows a negative insignificant correlation whilst leverage shows a positive insignificant relationship with the dependent variables. These are consistent with some arguments of previous researchers. He, Lepone \& Leung (2013) confirms that company size determines the level of disclosure. A large company is generally more complex than a small one, consequently requiring more information to be disclosed. Leuz \& Verrecchia (2000) support this argument and state that size should be negatively correlated since large sized companies will tend to have greater trading activities and disclose more information compared to small sized firms, hence lower the occurrence of information risk. As for the leverage, it is defined as the result if using fixed-cost asset in generating return (Gitman, 2009). Moreover, Gitman (2009) also pointed that it is usual that an increase in leverage will increase company risk and return. Accordingly, the high degree of leverage will give impact to high degree of financial risk to occur even though the companies try to disclose more information for the purpose of assuring and increasing shareholders confidence level in the market.

This result indicates that XBRLenv is deemed significant towards the dependent variable of ERV in the sample of the 3 countries. It shows a negative correlation with information risk. This finding is supported by previous studies that support stricter regulation in adopting XBRL as an open standard format for data structure and quality for reporting disclosures as it will lower the occurrence of information risk and further increase the intention of the stakeholders (investors, company, regulators, and government) to rely on the information provided by the company. The results indicate that after the adoption of XBRL, the sample companies will have a lower degree of information risk compared to prior to the adoption of

Table 4. The Result of Regression Analysis

\begin{tabular}{|c|c|c|c|c|c|}
\hline Variable & Coefficient & Std. Error & T-Statistics & p-Value & VIF \\
\hline Intercept $\left(\beta_{0}\right)$ & 0.784 & 0.115 & 6.806 & 0.000 & \\
\hline XBRLenv & -0.184 & 0.015 & -12.436 & 0.000 & 1.005 \\
\hline Size & -0.004 & 0.013 & -276 & 0.783 & 1.007 \\
\hline Leverage & 0.000 & 0.001 & 0.193 & 0.847 & 1.005 \\
\hline $\mathrm{R}^{2}$ & 0.305 & & & & \\
\hline Adjusted R2 & $29.90 \%$ & & & & \\
\hline F-Statistics & 55.059 & & & & \\
\hline Prob (F-Statistics) & 0.000 & & & & \\
\hline
\end{tabular}




\section{Jurnal Keuangan dan Perbankan | KEUANGAN}

Vol. 21, No. 4, Oktober 2017: 515-526

XBRL as a reporting standard technology. Other control variables appear to be insignificantly related to information risk, which is possibly explained by the fact that the adoption of XBRL for electronic reporting is gaining momentum in every country in the world except for Europe. However, the European parliament is still trying to improve the level of adoption of XBRL (Enachi \& Andone, 2015).

\section{CONCLUSION AND SUGGESTION}

\section{Conclusion}

The occurrence of information risk is expected to be reduced with the adoption of internet financial reporting technology of XBRL. XBRL as a technology used for reporting standard obtained by companies around the world to manage the quality and transparency of the reporting information by exchanging of information to stakeholders of various country in the world (Kim, Kim, \& No, 2011). The adoption of XBRL has had a positive impact on the lack of structured data format in reporting, as it will reduce the difficulty in understanding and analyzing the information provided by various companies (Alimohammadi, 2003). Most of the researchers are focusing on the occurrence of information asymmetry instead of information risk (Brown, Hillegeits, \& Lo, 2009). This is the main reason for the authors to contribute to the analysis related to information risk, especially in the Scandinavian region of the European Union. Therefore, the objective of the paper is to investigate whether the companies that adopt XBRL can lower the degree of information risk.

The ERV is an unexpected return where an abnormal (excess) return of stocks can imply towards the markets reactions (Bushee \& Noe, 2000). It is determined by the prices that investors discovered from the stock market due to the uncertainty of the future profitability of companies. In this study, ERV shows significant and valid re- sult to indicate the occurrence of information risk, which reflects that the adoption of XBRL results in a lower degree of information risk in these 3 countries in the European Union. Despite the fact that the adoption of XBRL in EU is taken step-bystep, the government still tries to improve the XBRL adoption, as it conveys a better improvement of the quality, efficiency, and transparency of the information determined by the lower level of information risk.

\section{Suggestion}

Towards the movement of XBRL adoption in many countries, it is importance to understand that the occurrence of information risk is not simple to detect. There are several factors that may affect, which include the transparency of information as well as quality of the information. Country's related regulation and environment might influence how the XBRL is adopted in its setting. Therefore, government should be aware of the risk occurrences, in which using XBRL as the main reporting standard may or may not bring an improvement towards the quality of the reporting disclosure, additionally length for development and improvement process also considered crucial.

For further research, it will be beneficial to investigate between the prior and post years of XBRL adoption as well as inclusion of more than one different measurements towards the occurrence of information risks such as total accrual quality, information efficiency, changes in standard deviation of analysts forecast and changes in standard deviation of daily stock returns in order to see profound impacts on the adoption.

\section{REFERENCES}

Alimohammadi, D. (2003). Meta-tag: A means to control the process of Web indexing. Online Information Review, 27(4), 238-242. 


\title{
The Impact of Adoption of XBRL on Information Risk in Representative Countries of Scandinavian Region
}

\author{
Valentina Tohang, Michellen Lan
}

Anagnostopoulou, S. C., \& Tsekrekos, A. E. (2015). Accounting quality, information risk, and implied volatility around earnings announcements. Journal of International Financial Markets, Institutions, and Money, 34, 188-207.

Beattie, V., \& Pratt, K. (2003). Issues concerning web-based business reporting: an analysis of the views of interested parties. The British Accounting Review, 35(2), 155-187.

Bhasin, M. (n.d.). XBRL: An innovative \& global financial reporting standard. http:// www.researchgate.net/profile/Madan_Bhasin/ p u b lic a ti o n / $271191365_{-}$X B R L _ AN_INNOVATIVE__GLOBAL_FINANCIAL_ REPOR T I N G_S T A N D A R D / 1 in k s / 54bf85240cf28ce68e6b5c6a.pdf

Blankespoor, E., Miller, B. P., \& White, H. D. (2014). Initial evidence on the market impact of the XBRL mandate. Review of Accounting Studies, 19(4), 1468-1503.

Bonsòn, E. (2001). The role of XBRL in Europe. The International Journal of Digital Accounting Research, 1(2), 101-110.

Bonsón, E., Cortijo, V., \& Escobar, T. (2009). Towards the global adoption of XBRL using International Financial Reporting Standards (IFRS). International Journal of Accounting Information Systems, 10(1), 4660.

Bonsón, E., \& Escobar, T. (2006). Digital reporting in Eastern Europe: An empirical study. International Journal of Accounting Information Systems, 7(4), 299-318.

Brown, S., Hillegeist, S. A., \& Lo, K. (2009). The effect of earnings surprises on information asymmetry. Journal of Accounting and Economics, 47(3), 208-225.

Bushee, B. J., \& Noe, C. F. (2000). Corporate disclosure practices, institutional investors, and stock return volatility. Journal of Accounting Research, 38, 171202.

CESR. (2010). Development of Pan-European access to financial information disclosed by listed companies. https:/ / www.esma.europa.eu/sites/default/files/library/2015/11/10_791c.pdf

Chen, Y. -C. (2012). A comparative study of e-government XBRL implementations: The potential of improving information transparency and efficiency. Government Information Quarterly, 29(4), 553-563.
Debreceny, R., \& Gray, G. L. (2001). The production and use of semantically rich accounting reports on the internet: XML and XBRL. International Journal of Accounting Information Systems, 2(1), 47-74.

Debreceny, R., Gray, G. L., \& Rahman, A. (2003). The determinants of internet financial reporting. Journal of Accounting and Public Policy, 21(4), 371-394.

Eierle, B., Ojala, H., \& Penttinen, E. (2014). XBRL to enhance external financial reporting: Should we implement or not? Case company X. Journal of Accounting Education, 32(2), 160-170.

Elky, S. (2006). An introduction to information systems risk management. Retrieved from https:// library.saylor.org/handle/1/1554

Enachi, M., \& Andone, I. I. (2015). The progress of XBRL in Europe-projects, users, and prospects. Procedia Economics and Finance, 20, 185-192.

ESMA. (n.d.). European securities and market authority. https:/ / www.esma.europa.eu/

European Commission. (n.d.). EU local offices and information points. https://ec.europa.eu/info/abouteuropean-union/organisational-structure/ locations_en

Francis, J., LaFond, R., Olsson, P., \& Schipper, K. (2005). The market pricing of accruals quality. Journal of Accounting and Economics, 39(2), 295-327.

Francis, J., Nanda, D., \& Wang, X. (2006). Re-examining the effects of regulation fair disclosure using foreign listed firms to control for concurrent shocks. Journal of Accounting and Economics, 41(3), 271-292.

Gaftea, V. (2014). Socio-economic major risks related to the information technology. Procedia Economics and Finance, 8, 336-345.

Gitman, L. J. (2009). Principal of Managerial Finance. US: Pearson Education Inc.

Hannon, N. (2005). XBRL fundamentals. Strategic Finance, $86(10), 57-58$.

He, W. P., Lepone, A., \& Leung, H. (2013). Information asymmetry and the cost of equity capital. International Review of Economics E Finance, 27, 611-620.

Inchausti, B. G. (1997). The influence of company characteristics and accounting regulation on information disclosed by Spanish firms. European Accounting Review, 6(1), 45-68. 


\section{Jurnal Keuangan dan Perbankan | KEUANGAN}

Vol. 21, No. 4, Oktober 2017: 515-526

Jiang, G., Lee, C. M., \& Zhang, Y. (2005). Information uncertainty and expected returns. Review of Accounting Studies, 10(2-3), 185-221.

Kernan, K. (2008). XBRL around the world. Journal of Accountancy, 206(4), 62

Kim, J. W., Kim, J. H., \& No, W. G. (2011). The effects of XBRL disclosures on information environment in the market: Early evidence. http:// eycarat.faculty.ku.edu/myssi/_pdf/1-Kim-LimNo-The \% 20Effects \% 20of\%20XBRL.pdf

Kothari, S. P., Li, X., \& Short, J. E. (2009). The effect of disclosures by management, analysts, and business press on cost of capital, return volatility, and analyst forecasts: A study using content analysis. The Accounting Review, 84(5), 1639-1670.

Lester, W. F. (2007). XBRL: The new language of corporate financial reporting. Business Communication Quarterly, 70(2), 226-231.

Leuz, C., \& Verrecchia, R. E. (2000). The economic consequences of increased disclosure (digest summary). Journal of Accounting Research, 38, 91-124.

Li, Y., Roge, J. N., Rydl, L., \& Crews, M. (2006). Information technology addresses transparency: the potential effects of XBRL on financial disclosure. Issues in Information Systems, 7(2), 241-245.

Lymer, A. (1999). Internet and the future of reporting in Europe. European Accounting Review, 8(2), 289-301.

Müller-Wickop, N., Schultz, M., \& Nüttgens, M. (2013). XBRL: Impacts, issues, and future research directions. Enterprise Applications and Services in the Finance Industry, 135, 112-130.

Ponte, E. B., Gallego, V. C., \& Rodríguez, T. E. (2009). A Delphi investigation to explain the voluntary adoption of XBRL. The International Journal of Digital Accounting Research, 9(15), 193-205.

Rayner, N., \& Chandler, N. (2008). XBRL will enhance corporate disclosure and corporate performance management. Gartner.
Sen, K. (2009). Earnings surprise and sophisticated investor preferences in India. Journal of Contemporary Accounting \& Economics, 5(1), 1-19.

Stocken, P. C., \& Verrecchia, R. E. (2004). Financial reporting system choice and disclosure management. The Accounting Review, 79(4), 1181-1203.

UK National Archives. (2011). The national archives: Identifying information assets and business requirements. http://www.nationalarchives.gov.uk/ documents/identify-information-assets.pdf

Venter, J. M. P. (2002). A survey of current online reporting practices in South Africa. Meditari Accountancy Research, 10(1), 209-225.

Verdi, R. S. (2006). Financial reporting quality and investment efficiency. SSRN. http://papers. ssrn.com/sol3/papers.cfm? abstract_id=930922

Verrecchia, R. E. (1983). Discretionary disclosure. Journal of Accounting and Economics, 5, 179-194.

Wang, T., Wen, C. Y., \& Seng, J.-L. (2014). The association between the mandatory adoption of XBRL and the performance of listed state-owned enterprises and non-state-owned enterprises in China. Information $\mathcal{E}$ Management, 51(3), 336-346.

Willis, M., Tesniere, B., \& Jones, A. (2003). Corporate communications for the 21st century. A White Paper Discussing the Impact of Internet Technologies on Business Reporting. http:/ / www.franzhoermann.com/ downloads / cor poratecommunicationsfor 21stcentury.pdf

Wu, J., \& Vasarhelyi, M. (2004). XBRL: A new tool for electronic financial reporting. Business Intelligence Techniques, 73-92.

XBRL. (n.d.). A survey of XBLR Implementations 2013. http:// archive.xbrl.org/26th/sites / 26 thconference.xbrl.org/files/DATA1 SurveyofImplementations.pdf

Yoon, H., Zo, H., \& Ciganek, A. P. (2011). Does XBRL adoption reduce information asymmetry? Journal of Business Research, 64(2), 157-163. 